Article

\title{
Climate Change and Economic Growth: The Role of Environmental Policy Stringency
}

\author{
Enrico Maria de Angelis ${ }^{1}$, Marina Di Giacomo ${ }^{1(\mathbb{D})}$ and Davide Vannoni ${ }^{1,2, *(\mathbb{C})}$ \\ 1 ESOMAS Department, University of Torino; 10124 Torino, Italy; enrico.deangelis@edu.unito.it (E.M.d.A.); \\ marina.digiacomo@unito.it (M.D.G.) \\ 2 Collegio Carlo Alberto, 10122 Torino, Italy \\ * Correspondence: davide.vannoni@unito.it; Tel.: +39-011-6706083
}

Received: 17 January 2019; Accepted: 11 April 2019; Published: 16 April 2019

\begin{abstract}
The paper investigates the relationship between economic growth and environmental quality in the context of the Kuznets curve, which foresees that growth, while initially causing negative externalities for the environment, eventually can be seen also as the solution to environmental degradation. The novelty of the paper is to analyze the role of environmental policies, and in particular the use of market-based and non-market instruments to challenge the pollution plague and mitigate climate change. The results of fixed effects estimates on a sample of 32 countries observed for the period 1992-2012 show the existence of an inverted U-shaped relationship between per capita gross domestic product (GDP) and per-capita $\mathrm{CO}_{2}$ emissions for the quadratic specification, as well as of an $\mathrm{N}$-shaped pattern for the cubic specification. Most importantly, the stringency indexes, i.e., the proxies used to account for environmental regulation, exhibit negative and strongly significant coefficients, suggesting that the policies are effective in reducing environmental damages associated with economic growth.
\end{abstract}

Keywords: Environmental Kuznets's curve; environmental policies; stringency index

JEL Classification: Q54; Q56; Q58

\section{Introduction}

Climate change and environmental pollution are two intertwined topics, whose relevance is increasing year by year. According to the OECD [1], pollution plays a role in more than $80 \%$ of major diseases. Emissions can have a direct impact (on health, on environmental degradation) in the short run, as in the case of sulfur dioxide $\left(\mathrm{SO}_{2}\right)$, or in the long run, as in the case of carbon dioxide $\left(\mathrm{CO}_{2}\right)$. While they can be due to natural activities (such as volcanic eruption), industrial production and particularly the consumption of fossil fuels account for most emissions [2]. Figure 1 shows the growing relevance of Asian countries in increasing the levels of emissions in the period 1992-2012, while Figure 2 shows that emissions per capita are very high in North America and Europe and are increasing sharply in the East Asia and Pacific region, with a leading role played by China. It is also interesting to note the impact of the financial crisis that around 2008 and 2009 leads to a decrease in $\mathrm{CO}_{2}$ emissions in North America, Europe and Central Asia, and East Asia and Pacific. After the crisis, all the regions start increasing their emissions again, but the slopes of the lines show different rates of growth. 


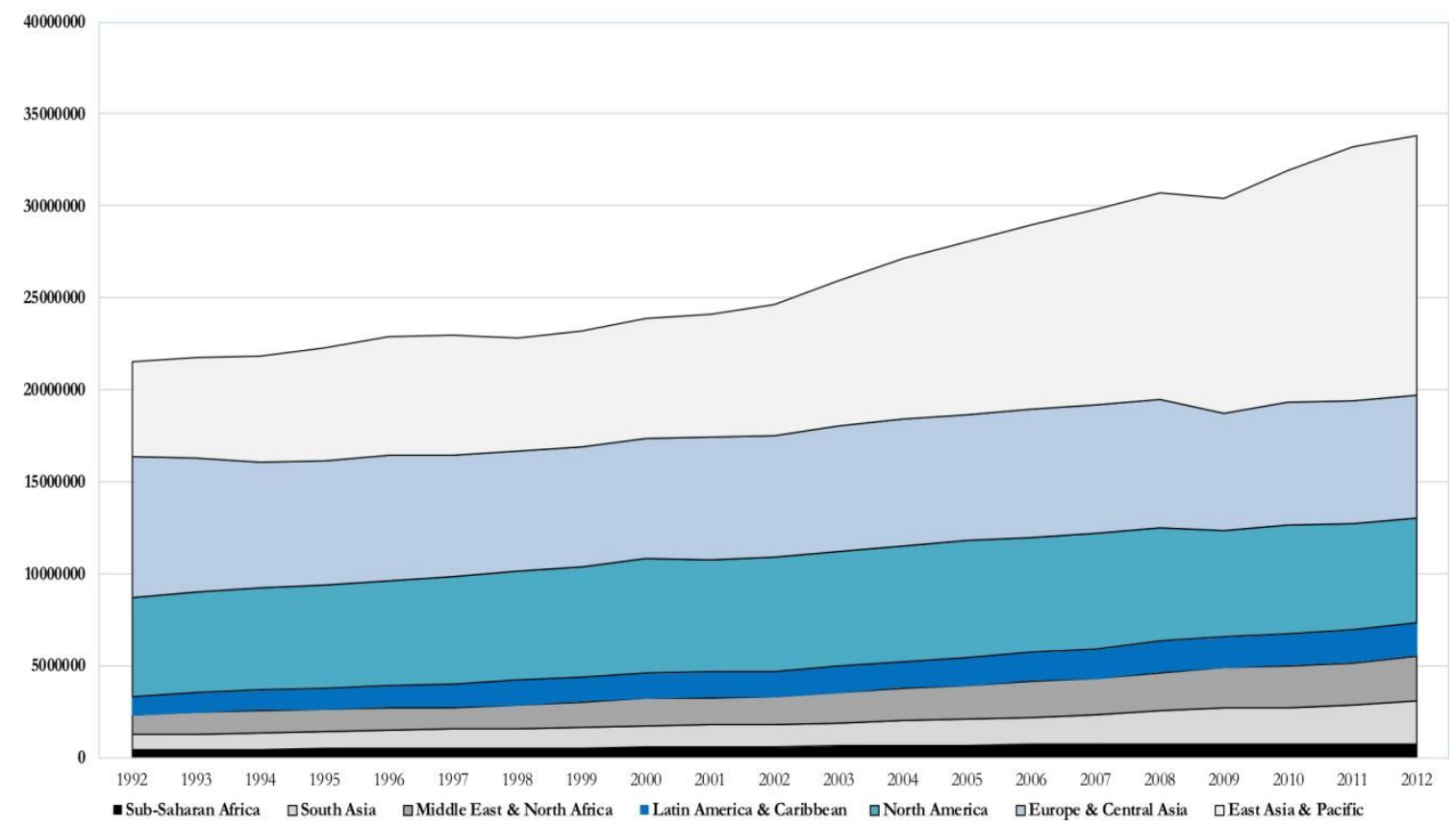

Figure 1. Worldwide $\mathrm{CO}_{2}$ emissions (total amounts), by geographic region, 1992-2012. Values in kt. (Data source: World Bank.).

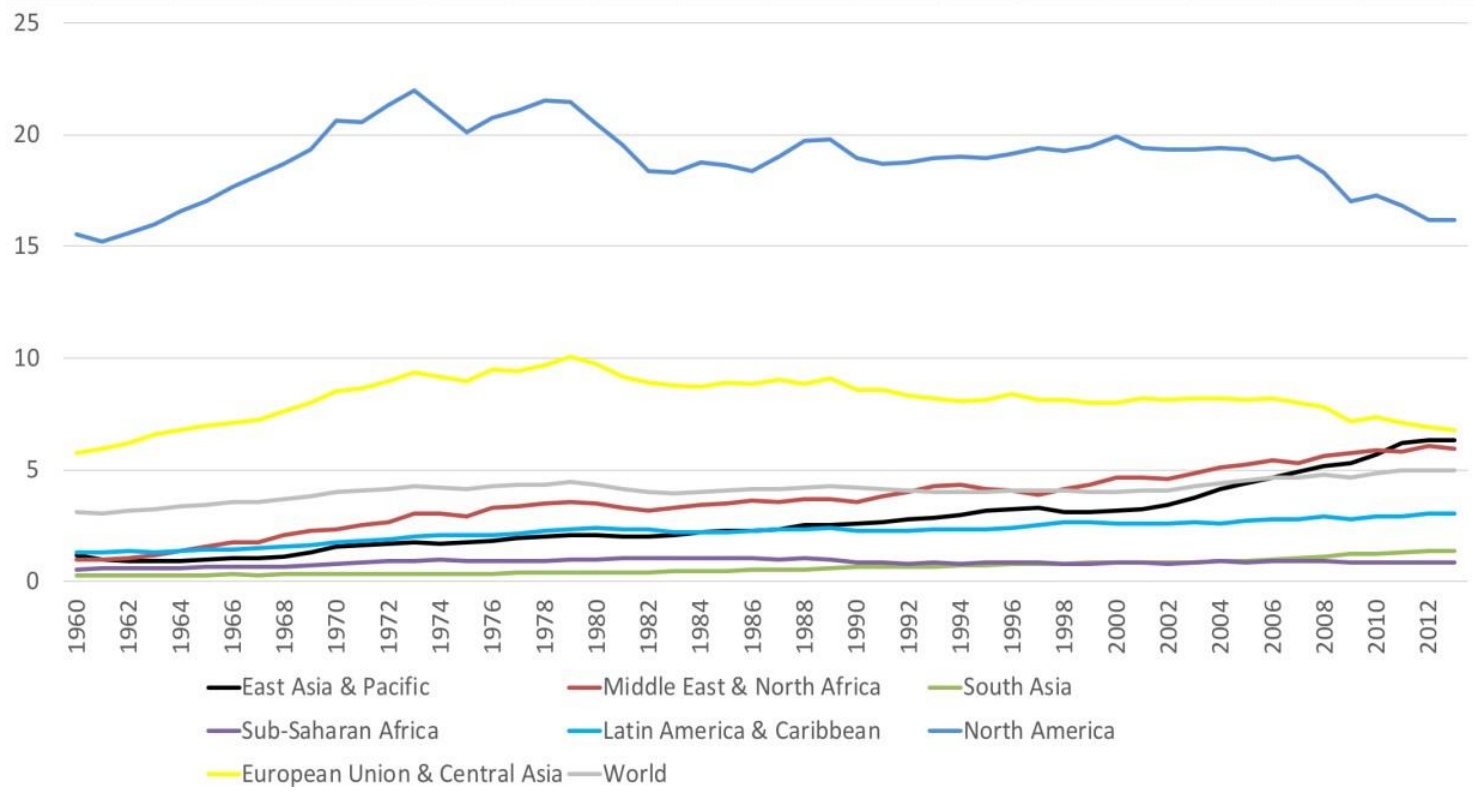

Figure 2. World's $\mathrm{CO}_{2}$ emissions per capita (metric tons), by region. 1960-2013. (Data source: World Bank.).

International cooperation is essential to guide countries towards low carbon practices to contrast a worldwide problem such as global warming. The first attempt in the direction of a worldwide commitment to reduce greenhouse gas emissions (GHGs) was achieved in 1992, with the United Nations Framework Convention on Climate Change (UNFCCC), signed during the Earth Summit in Rio de Janeiro by 154 countries. The overall aim was the one of reducing $\mathrm{CO}_{2}$ emissions, with different responsibilities for developed and developing countries. During the subsequent Conferences of the Parties (COP), held in Berlin in 1995, in Geneva in 1996, and in Kyoto in 1997, the forecasted future relevance of GHGs of developing countries became a central topic. The Kyoto Protocol entered into force in February 2005, and involved 192 countries. The focus was the reduction of the four 
major GHGs responsible for the global warming: Carbon Dioxide, Methane, Nitrous Oxide, and Sulfur Hexafluoride. The tools suggested for developed countries, in an attempt of controlling the anthropogenic emissions, are: International Emission Trading (IET), Clean Development Mechanism (CDM), and Joint Implementation (JI). These tools allow the countries to create a system of credits to be traded, leading to the creation of the cap-and-trade system. However, a global price of carbon was not specified, and developing countries were still ousted from the commitment. Moreover, Canada, by withdrawing from the Agreement and the US, by not ratifying it, were behaving as free-riders. In the Paris Agreements in 2015, the environmental target finally moves from a country-base perspective to a worldwide one. The Agreement establishes a global warming goal of well below $2{ }^{\circ} \mathrm{C}$ on pre-industrial averages and limits the increase in temperature to $1.5^{\circ} \mathrm{C}$. It requires the countries to formulate progressively more ambitious climate targets, consistent with the thresholds. To achieve this target, all the parties of the Paris Agreement will need to make profound changes in their economies. The Paris Agreement still recognizes different responsibilities between developed and developing countries, but, for the first time, it establishes the obligation of all parties to contribute to climate change mitigation.

Many Governments try to implement the directives promulgated by the International Agreements and devise special instruments in an attempt to reduce pollution emissions and the connected environmental problems, using different tools.

This paper contributes to the discussion by testing on a sample of 32 countries observed in the period 1992-2012 for the existence of the so-called Environmental Kuznets Curve (EKC) that links GDP per capita to $\mathrm{CO}_{2}$ emissions per capita. The results in the literature are still mixed, and depend on the pool of countries included in the analysis, on the time span, and on the functional form used to estimate the impact of production on the level of emissions. To consider country and time specificities, a fixed effects model is run, and separate estimates are provided for European countries and non-European countries and for different time periods. A novelty in our approach is the evaluation, for the world's major producers of greenhouse gases, of the effectiveness of environmental regulation, using as a measure of the strictness of the policies applied by the different countries the Stringency Index (SI) recently introduced by Botta and Kozluk [3], and distinguishing between market-based instruments and non-market ones.

In particular, the focus is on the sign and the magnitude of some empirical proxies for the commitment and the stringency of environmental policy measures. This is an important issue that only recently obtained some attention in the EKC literature. We argue that the presence of environmental policies may contribute to emission reductions. However, it is important to assess the impact of 'the way' these policies are implemented, i.e., their severity and rigorousness. We thus aim to contribute to the stream of literature on the impact of environmental policy stringency and the concerns about its effectiveness (Porter and van der Linde [4], Ambec et al. [5]).

One of the main results of our analysis is the heterogeneity in the $\mathrm{CO}_{2}$ emissions reduction, depending on the stringency of the implemented policies. We find that more rigorous environmental policies actually reduce emissions and this is particularly true for: (i) more committed countries (European Union member states) when compared to less-committed countries (non-European Union member states); (ii) the post 2005 period, when the European Emissions Trading System and the Kyoto Protocol became effective. Free-riding problem is still central, likely causing a slow-down in the abatement process. International cooperation and international peer control should push towards a worldwide effort. Also, the innovation channel is called for: technological improvements, innovative products and new processes can accelerate the process of compliance, triggering a virtuous circle for emissions reduction.

The remainder of the paper is organized as follows. Section 2 briefly reviews the relevant literature on the EKC. Section 3 discusses the main instruments used to contrast global warming and environmental pollution. Section 4 presents the data, Section 5 introduces the econometric model, while Section 6 shows our main results. Section 7 concludes. 


\section{Literature Review}

The Kuznets curve was firstly introduced by Kuznets in 1955 [6], to investigate the nexus between income and income inequality. The curve shows that an initial growth in income is associated with a sharp increase in the income inequalities. However, after a certain "breakeven" point, the inequalities tend to decrease as far as income increases. Grossman and Krueger $[7,8]$ were the first to apply the so-called EKC, which postulates an inverse U-shaped relationship between GDP per capita and an environmental degradation indicator. At relatively low levels of per capita GDP, per capita emissions increase with economic growth. After per capita emissions reach a maximum, they start to decline as per capita GDP continues to grow.

While no formal theory was used to develop the EKC, Grossman and Krueger $[7,8]$ argued that the increasing industrialization, associated with economic growth, would yield initially an increase in per capita emissions but, after reaching a certain threshold (the turning point), environmental quality should improve with further economic growth. This pattern describes the evolution of a country that switches from an industrial society that harms the Earth's environment to an economic system in which citizens are more concerned about the safeguard of the environment, and where cleaner technologies replace dirty ones. However, this two-sided curve also depicts a two-fold effect: while economic development may be environmentally beneficial in the long run, it may heavily, and irreversibly, destroy the environment in the short run.

Grossman and Krueger [7,8] estimated the relationship between GDP per capita, chosen as the income indicator, and air pollutants such as sulfur dioxide and suspended particulate matter, chosen as environmental indicators, on a sample of 42 countries observed for several years. While they adopted a cubic functional form, the results were in favor of the existence of an inverse U-shaped relationship. Shafik and Bandyopadhyay [9] used 10 different environmental indicators to test for the existence of a bell-shaped relation. The dataset covered 149 countries for the years 1960-1990, and different functional forms (log-linear, log-quadratic, and log-cubic polynomial) were tested. Results showed that the bell-shaped curve emerged only for two of the ten environmental indicators they adopted. These ambiguous findings are a clear sign of the complex nexus between economic growth and environmental sustainability. Panayotou [10] estimated the EKC using four different environmental indicators and data from the late 1980s. Using a log-quadratic function on cross-sectional data, he found that the EKC curve was holding for all the estimates. Holtz-Eakin and Selden [11] examined the relationship between per capita $\mathrm{CO}_{2}$ emissions and GDP per capita. The analysis covered 130 countries observed for the years 1951-1986. The results of panel data regressions for the quadratic specification were in favor of the presence of an inverted U-shaped relationship, while an N-shaped curve was detected for a cubic specification. The four previous seminal studies can be considered as the "cornerstone" of the literature. Ozocku and Ozdemir [12] present an updated review of the empirical literature, concluding that after 25 years of research, results are still very heterogeneous. Galeotti et al. [13] summarize by stating that: "The EKC hypothesis remains a fragile concept". The differences are due to the selection of countries, to the estimation method applied, to the type of pollutant and the type of explanatory variables included in the analysis, and to the functional form chosen for the estimation. For more details, the interested reader may refer to the excellent surveys made by Dinda [14], by Ozocku and Ozdemir [12] and by Lee et al. [15]. See also [16,17] for very recent applications that use GHGs (of European Union (EU) countries) and ecological footprint (of three Eastern Asian Countries) as left-hand side variables.

The different shapes of the curves are implying different views on environmental sustainability. First, there can be monotonically increasing (decreasing) curves, meaning that environmental quality gets worse (better) as income increases. The inverted U-shape suggested by the EKC posits that environmental quality worsens with the rise in income up to a peak, after which environmental quality can improve with economic growth. The $\mathrm{N}$-shaped curve depicts a situation in which environmental degradation at first worsens and then improves as far as income increases, but eventually worsens again after income reaches a second turning point (trough). If the data reveal an $\mathrm{N}$-shaped function 
instead of an inverted U-shaped one, it means that economic growth cannot be considered as both the cause and the solution to environmental degradation, and government interventions to structurally abate emissions are much more urgent and relevant as compared to the case in which a bell-shaped curve is detected.

To that respect, the specific role of environmental regulation and of political institutions of the different countries [18] are rarely taken into consideration in empirical studies of the EKC. Lagreid and Povitkina [19] argue that "nation states decide whether to sign and/or ratify international agreements related to $\mathrm{CO}_{2}$ emission reduction and adopt international prescriptions in their national legislation. By means of laws and regulations they have the power to shape the behavior of firms operating on their territories and guide choices of their citizens". By using a sample of 140 countries over the period 1972-2014, they found that per capita $\mathrm{CO}_{2}$ elasticity of GDP was diminishing in countries with democratic non-corrupt governments and high civil society participation. As to the role of environmental regulation, a recent paper by Shapiro and Walker [20] shows that the changes in environmental policies account for most of the reduction of air pollutions emissions that the US, notwithstanding an increase in manufacturing output, experienced in the period 1990-2008. In line with these contributions, we enrich our EKC specification by including measures of the stringency of environmental policies.

The stringency of environmental policies is usually tackled within the more general framework of the effectiveness of environmental policies and the trade-off between policy severity and the productivity and the competitiveness of industries / countries with more binding regulation. Two opposing views confront on the issue: on the one side, scholars assert that environmental quality and competitiveness are incompatible targets (Levinson and Taylor [21]), while on the other side many authors find that a green growth path is viable and effective (Ambec et al. [5]). Regulation can positively influence competitiveness and productivity through the channel of innovation: a stringent regulation produces greater innovation as compliance requires more effort towards innovative product and new process solutions (Porter and van der Linde [4]). It thus becomes crucial to correctly assess the stringency of environmental policies, as only stringent policies can have beneficial effects on the economy as a whole. Several indicators have been proposed in the literature and each of them has several advantages and limitations due to the multi-dimensionality of any environmental policies (Brunel and Levinson [22], Fisher and Newell [23], and Galeotti et al. [24]). In general, indicators convey different information, and country rankings often differ according to the chosen stringency measure.

\section{Market-Based and Non-Market Instruments}

Different instruments can be adopted to correct market failures, such as environmental externalities, to reach the sustainability targets set by the International Agreements. According to De Serres et al. [25] and Azuela et al. [26], it is common practice to divide the set of environmental policies into market-based and non-market instruments.

Market-based instruments are classified as the ones defining a price for the inputs or the goods that, during production or consumption, emit negative externalities. The most popular ones are:

i. Environmentally related taxes, i.e., taxes on the source of emissions, such as the carbon tax, or taxes on inputs and outputs used in the production process, such as taxes on water usage, packages, pesticides, fuel excises;

ii. Tradeable pollution emissions permit systems (cap-and-trade). Basically, a cap-and-trade system sets a maximum level of pollution, and distributes emissions permits among firms generating emissions. Companies must have permits to pollute, and get them either through an initial allocation or auction, or through trading with other firms, thanks to the creation of a secondary market. Since some firms inevitably find it easier or cheaper to reduce pollution than other, trading takes place. While the maximum pollution quantity is set in advance, the trading price of permits fluctuates, becoming more expensive (cheaper) when demand is relatively high (low) with respect to supply. A price on pollution is therefore created as a result of setting a ceiling on the overall quantity of emissions. 
Placing a tax upon a polluting activity, or allowing to pollute only if a license is held, produces an incentive to innovate over time, both by introducing new technologies and by using available technologies more effectively. Some authors tend to consider carbon taxes and cap-and-trade tools as equivalents [27], at least for what concerns the aims of the instruments. Despite being equivalent in many ways, the two types of instruments have important differences. For example, a carbon tax goes to directly change the price of carbon, and the related change in $\mathrm{CO}_{2}$ emissions is an adjustment realized over time, while cap-and-trade goes to directly reduce the emissions, imposing a maximum amount, so that the change in price is an indirect effect.

According to the OECD [28]: "Pricing instruments encourage broad-based action to reduce environmental damage at least cost and should be a central pillar of green growth policy. They provide incentives for further efficiency gains, green investment, and innovation and shifts in consumption patterns. Increased or more effective use of environmentally related taxes can drive growth-oriented reform by shifting the tax burden away from more distortive taxes, e.g., on corporate or personal income, and contribute to fiscal consolidation." A clear challenge is shifting the focus from the tax burden towards an environmentally related taxation, to achieve a double positive result, known as the "double-dividend" gain. The double-dividend hypothesis suggests that increased taxes on pollution can provide two kinds of benefits. The first is an improvement in the quality of the environment, and the second is an efficiency gain from using the environmental tax revenues to reduce other taxes, such as income taxes, that distort labor supply and saving decisions [29]. Northern Europe countries, such as Finland, Norway, Sweden, and Denmark, started implementing a carbon tax system in the early 1990s, showing a pioneering role in environmentally related regulation. From 2005 to 2015, many other European countries (France, Switzerland, Liechtenstein, Latvia, Portugal, Ireland, Iceland) have applied a carbon tax structure. After 2015, due to various independent initiatives in US cities and in Asian countries, the carbon tax continued to spread. In 2005, a European Trading System (ETS) has been implemented within the EU borders. According to the World Bank [30], the first two national ETS initiatives, after the EU comprehensive one, have been in Switzerland and in New Zealand, both in 2008. Then, from 2010 to 2015, the cap-and-trade system has been implemented in cities such as Tokyo, Shenzhen, Shanghai, and Beijing, but the most relevant implementation is surely the recent China national ETS.

Non-market instruments can be classified into two broad categories:

i. Command-and-control regulation, i.e., standard setting. Some examples are the setting of the maximum level of emissions or the imposition of the composition of fuels that need to be used in production or consumption (i.e., a specific fuel with low level of carbon);

ii. Active technology-support policies. The aim of active technology-support policies is to subsidize and stimulate the investments in the renewable energies sector. The set of instruments include public investments in environment-related $R \& D$, the use of public procurement to foster green activities, the provision of public funds to stimulate private R\&D.

Such policies are not considered market-based because of the direct imposition of the decision by the government, with no market adjustment process of prices and quantities.

\section{Data Description}

Our dataset refers to 32 countries (The considered countries are: Australia, Austria, Belgium, Canada, Czech Republic, Denmark, Finland, France, Germany, Greece, Hungary, Ireland, Italy, Japan, Republic of Korea, Netherland, Norway, Poland, Portugal, Slovak Republic, Spain, Sweden, Switzerland, Turkey, United Kingdom, United States, Brazil, China, India, Indonesia, Russia, and South Africa.) observed over the period 1992-2012 (a balanced panel). The limit to the number of countries and to the time horizon is due to data constraints. In particular, $\mathrm{CO}_{2}$ emissions are not available for some Eastern European countries (Slovak Republic, Czech Republic and Poland) for years prior to 1992. The SI is available until 2015; however, the coverage reduces from 32 to only 16 countries after 
2012. For these reasons, our final sample is limited to the period 1992-2012. Nonetheless, our final sample covers, on average, more than $90 \%$ of the world's $\mathrm{CO}_{2}$ emissions.

$1 \mathrm{CO}_{2}$, the dependent variable, is defined as the logarithm of per capita metric tons of $\mathrm{CO}_{2}$ emissions. Our main explanatory variables are GDP, energy consumption, urbanization and, most importantly, the SI. The logarithm of GDP per capita (IGDP) is measured at 2011 exchange rates purchasing power parity, using World Bank data. Its squared term $\left(\mathrm{GDP}^{2}\right)$ is included in the quadratic specification, and $1 G D P^{2}$ and $1 G D P^{3}$ are included in the cubic specification. IENUSE reflects energy consumption, and is measured in log of $\mathrm{kg}$ of oil equivalent per capita. Following the literature, we expect that an increase in energy consumption would lead to an increase in $\mathrm{CO}_{2}$ emissions [31]. URB is the urbanization rate, and is expected to be positively signed. We use the World Bank databases as the data source for all these variables (1CO2, 1GDP, 1ENUSE, and URB).

The SI is a recent measure proposed by Botta and Kozluk [3] and it is freely distributed by the OECD. Dissatisfied by the lack of reliable and comparable measures of the stringency of environmental policies, they devised a new composite index that proxies for the severity of the policies applied by the different governments. The index is comprehensive of the most important instruments that can be applied by the governments in order to reduce the impact of pollution by firms and consumers, such as limits to pollutants, government energy-related R\&D expenditures, feed in tariffs (e.g., solar and wind feed in tariffs), taxes, certificates, deposit, and refund schemes. The instruments are primarily related to climate and air pollution and are weighted and aggregated to form a composite index of environmental policy stringency. The aim is to depict the costs of polluting, and, in particular, these indexes measure the extent to which it becomes costlier for a firm to undertake a "bad" environmental behavior, on a year-by-year basis. For example, an increase in taxation means an increase in the SI, and the same applies to an increase in the subsidies to renewable energy or energy schemes, since they raise the opportunity cost of polluting. Other similar indices have been proposed in the literature [24,32-35], but we opted for the SI by OECD, in that it is one of the most recent indexes, it is available for a wide time horizon and for a large set of countries, and, more importantly, it is split between market ( $\left.\mathrm{SI}_{\mathrm{MKT}}\right)$ and non-market instruments $\left(\mathrm{SI}_{\mathrm{NMKT}}\right)$. Figures 3 and 4 show an increasing trend in the severity of the policies, especially after 2000. The SIs range between 0 and 6 , where 0 is the lowest stringency level, and 6 is the highest. Since 2009, no country has anymore a zero value for the market-based instruments SI. Our expectation is that both $\mathrm{SI}_{\mathrm{MKT}}$ and $\mathrm{SI}_{\mathrm{NMKT}}$ are effective in reducing $\mathrm{CO}_{2}$ emissions.

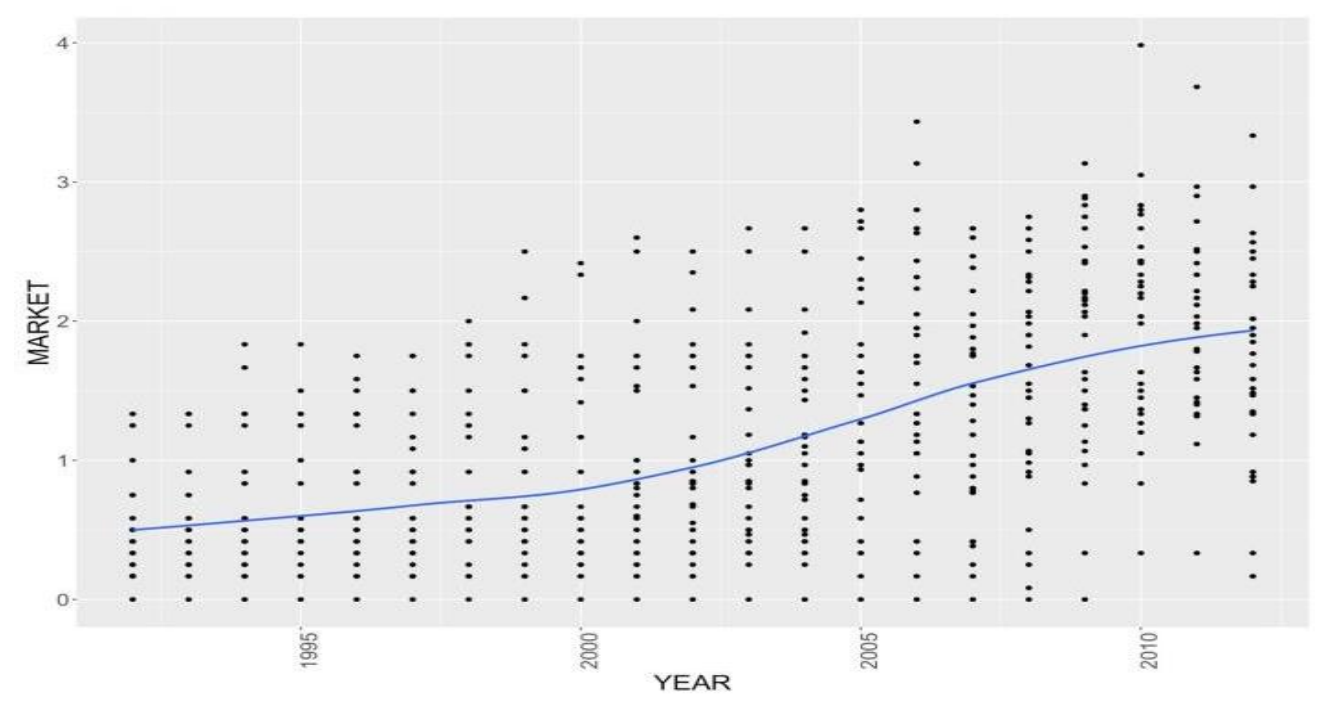

Figure 3. Trends in the stringency of market-based instruments $\left(\mathrm{SI}_{\mathrm{MKT}}\right)$. 


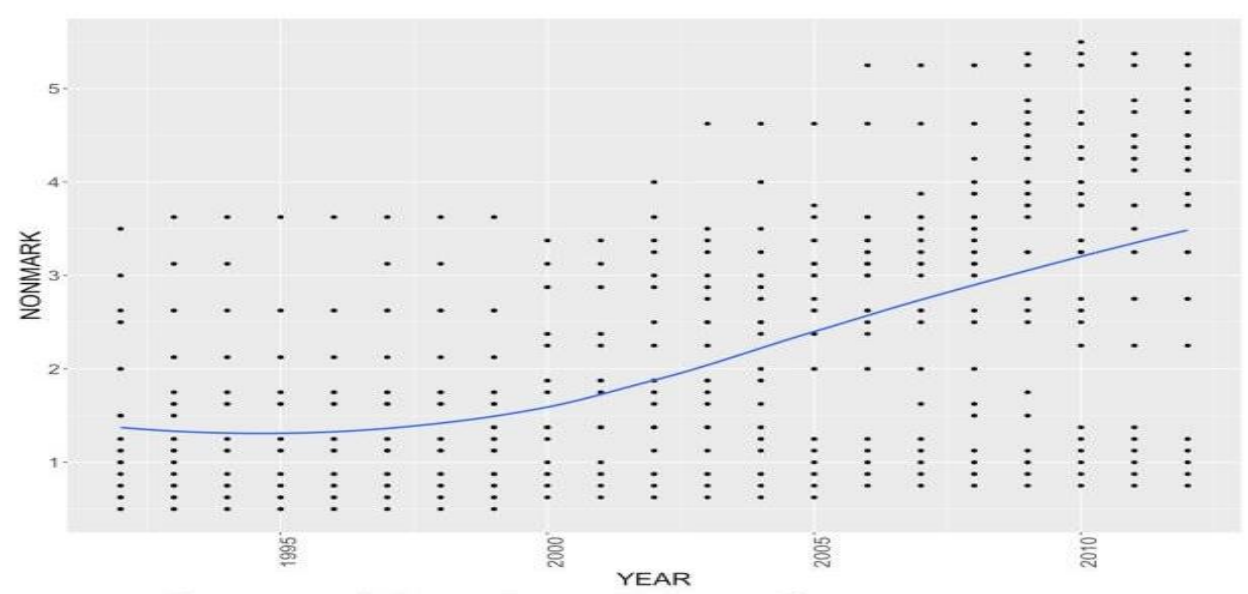

Figure 4. Trends in the stringency of Non-Market instruments $\left(\mathrm{SI}_{\mathrm{NMKT}}\right)$.

Table 1 provides the summary statistics of our key variables. Please note that the mean of $\mathrm{SI}_{\mathrm{NMKT}}$ is twice as big as the mean of $\mathrm{SI}_{\mathrm{MKT}}$, highlighting that non-market instruments are more stringent than market-based ones. Note also that $\mathrm{CO}_{2}$ emissions vary a lot between countries, ranging from a minimum of 0.771 metric tons per capita (value -0.26 in logarithmic transformation) scored by India in 1992 to a maximum of 20.179 (value 3 in logarithmic transformation), level reached by the US in 2000.

Table 1. Descriptive Statistics.

\begin{tabular}{ccccccc}
\hline & 1CO $_{\mathbf{2}}$ & 1GDP & 1ENUSE & URB(\%) & SI $_{\text {MKT }}$ & SI $_{\text {NMKT }}$ \\
\hline Mean & 1.96 & 10.08 & 8.04 & 70.70 & 1.11 & 2.11 \\
Median & 2.12 & 10.35 & 8.18 & 73.73 & 0.92 & 1.75 \\
Standard Deviation & 0.66 & 0.72 & 0.66 & 14.79 & 0.81 & 1.24 \\
Minimum & -0.26 & 7.49 & 5.90 & 25.98 & 0.00 & 0.50 \\
Maximum & 3.00 & 11.08 & 9.04 & 97.73 & 3.98 & 5.50 \\
Observations & 671 & 671 & 671 & 671 & 671 & 671 \\
\hline
\end{tabular}

Finally, Table 2 shows the correlation matrix, which is computed using the Pearson method with list-wise deletion. While there is a clear positive correlation between emissions and GDP, it is interesting to check if GDP can be also seen as the solution to the environmental problem.

Table 2. Correlation Matrix.

\begin{tabular}{|c|c|c|c|c|c|c|}
\hline & $1 \mathrm{CO}_{2}$ & 1GDP & 1ENUSE & URB(\%) & SIMKT $_{\text {MKT }}$ & SI $_{\text {NMKT }}$ \\
\hline $1 \mathrm{CO}_{2}$ & 1 & $0.725^{* * *}$ & $0.872^{* * *}$ & $0.641^{* * *}$ & $0.165^{* * *}$ & $0.321^{* * *}$ \\
\hline 1GDP & & 1 & $0.828^{* * *}$ & $0.774^{* * *}$ & $0.421^{* * *}$ & $0.613^{* * *}$ \\
\hline IENUSE & & & 1 & $0.764^{* * *}$ & $0.233^{* * *}$ & $0.436^{* * *}$ \\
\hline URB(\%) & & & & 1 & $0.287^{* * *}$ & $0.423^{* * *}$ \\
\hline $\mathrm{SI}_{\mathrm{MKT}}$ & & & & & 1 & $0.618^{* * *}$ \\
\hline $\mathrm{SI}_{\mathrm{NMKT}}$ & & & & & & 1 \\
\hline
\end{tabular}

\section{Econometric Model}

According to the Kuznets curve, the relation between $\mathrm{CO}_{2}$ emissions and GDP should be represented by an inverted U-shaped function. A scatter plot of the data (Figure 5) seems to show the presence of a bell-shaped curve, and the peak is approximately at 10.6, which is in correspondence of a GDP per capita of 40,000 US dollars. 


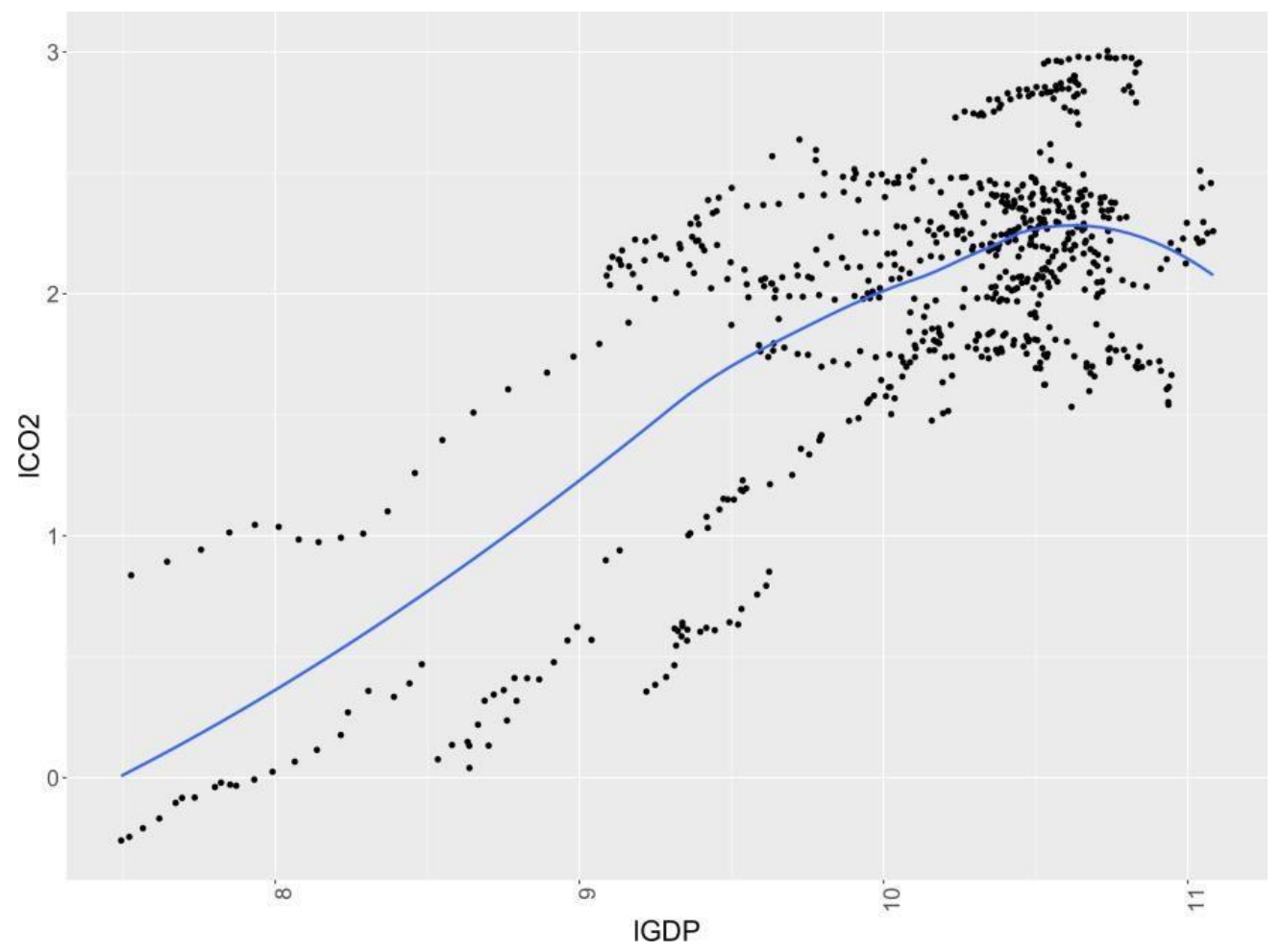

Figure 5. Inverted U-Shaped Kuznets Curve, scatter plot of the data.

The classical specification for the EKC is quadratic in the GDP term. We enrich the regression by including $1 \mathrm{ENUSE}, \mathrm{URB}, \mathrm{SI}_{\mathrm{MKT}}$, and $\mathrm{SI}_{\mathrm{NMKT}}$ as right-hand side variables, as well as country fixed effects to account for unobservable country specific time invariant characteristics.

The equation we estimate is therefore:

$$
l C O 2_{i t}=\beta_{0 i}+\beta_{1} l G D P_{i t}+\beta_{2} l G D P_{i t}^{2}+\beta_{3} S I M K T_{i t}+\beta_{4} S I N M K T_{i t}+\beta_{5} l E N U S E_{i t}+\beta_{6} U R B_{i t}+\varepsilon_{i t}
$$

As discussed in Section 2, the results on the empirical literature on the EKC are highly heterogeneous, and the differences are due to the variety of pollutants analyzed, to the different samples selected, to the different time horizons, and to the specification of the econometric model, too. Therefore, a cubic model specification, which adds the term $1 G^{-1} P^{3}$ to equation (1), allows the function to have two turning points, and to test for the existence of both (local and global) maximum and minimum points:

$$
\begin{aligned}
l C O 2_{i t}= & \beta_{0 i}+\beta_{1} l G D P_{i t}+\beta_{2} l G D P_{i t}^{2}+\beta_{3} l G D P_{i t}^{3}+\beta_{4} S I M K T_{i t}+ \\
& \beta_{5} S I N M K T_{i t}+\beta_{6} l E N U S E_{i t}+\beta_{7} U R B_{i t}+\varepsilon_{i t}
\end{aligned}
$$

It is interesting to verify the existence of some heterogeneity across countries. To do so, we focus on two sets of countries: EU members and non-EU countries. This would allow us to ascertain whether the application of the "different responsibilities" principle, designed in the International Agreements, has an impact on the reduction of the emissions or not. We thus enrich models (1) and (2) by adding two interacted terms, $\mathrm{EU}^{*} \mathrm{SI}_{\mathrm{MKT}}$ and $\mathrm{EU}^{*} \mathrm{SI}_{\mathrm{NMKT}}$, where $\mathrm{EU}$ is a dummy that takes a value equal to 1 for EU countries and zero otherwise:

$$
\begin{gathered}
l C O 2_{i t}=\beta_{0 i}+\beta_{1} l G D P_{i t}+\beta_{2} l G D P_{i t}^{2}+\beta_{3} \operatorname{SIMKT}_{i t}+\beta_{4} \operatorname{SINMKT}_{i t}+\beta_{5} l E N U S E_{i t}+ \\
\beta_{6} U R B_{i t}+\beta_{7} E U * \operatorname{SIMKT}_{i t}+\beta_{8} E U * \operatorname{SINMKT}_{i t}+\varepsilon_{i t}(1 a)
\end{gathered}
$$




$$
\begin{gathered}
l C O 2_{i t}=\beta_{0 i}+\beta_{1} l G D P_{i t}+\beta_{2} l G D P_{i t}^{2}+\beta_{3} l G D P_{i t}^{3}+\beta_{4} \operatorname{SIMKT}_{i t}+\beta_{5} S_{I N M K T_{i t}}+ \\
\beta_{6} I E N U S E_{i t}+\beta_{7} U R B_{i t}+\beta_{8} E U * S I M K T+\beta_{9} E U * S I N M K T+\varepsilon_{i t}(2 a)
\end{gathered}
$$

\section{Results}

Results for model (1) are shown in the first three columns of Table 3. All coefficients are different from zero and with the expected sign. The positive effect of 1GDP and the negative coefficient of its squared term point towards the presence of an inverted U-shape. The maximum of the bell is reached when IGDP is around 8.2, i.e. when GDP per capita is about 3.640 US dollars. Note the difference with respect to the simple plot of data of Figure 5, where the threshold was at 40.000 US dollars. This is due to the introduction of country fixed effects. In fact, by running a simple Ordinary Least Squares (OLS) regression on the pooled data, the turning point is reached when IGDP is 10.4, a figure very close to the peak depicted in Figure 5. However, the pooled regression may distort the true picture of the relationship, because some historical and economic factors, which are unobservable, country specific, and time invariant, may play a crucial role. Indeed, a Fisher Test is strongly in favor of a fixed effects model.

Most importantly for our analysis, $\mathrm{SI}_{\mathrm{MKT}}$ and $\mathrm{SI}_{\mathrm{NMKT}}$ are effective in reducing emissions, both when added separately (first two columns of Table 3) and jointly (third column of Table 3). However, the non-market instruments seem to be more effective, both for the higher significance and for the magnitude of the coefficient itself.

\begin{tabular}{|c|c|c|c|c|}
\hline & (1) & (2) & (3) & (4) \\
\hline 1GDP & $\begin{array}{c}0.888^{* * *} \\
(0.13)\end{array}$ & $\begin{array}{c}0.762^{* * *} \\
(0.14)\end{array}$ & $\begin{array}{c}0.736^{* * *} \\
(0.14)\end{array}$ & $\begin{array}{c}0.684^{* * *} \\
(0.13)\end{array}$ \\
\hline $1 G D P^{2}$ & $\begin{array}{c}-0.054^{* * *} \\
(0.01)\end{array}$ & $\begin{array}{c}-0.046^{* * *} \\
(0.01)\end{array}$ & $\begin{array}{c}-0.045^{* * *} \\
(0.01)\end{array}$ & $\begin{array}{c}-0.039^{* * *} \\
(0.01)\end{array}$ \\
\hline $\mathrm{SI}_{\mathrm{MKT}}$ & $\begin{array}{c}-0.012^{* * *} \\
(0.00)\end{array}$ & & $\begin{array}{c}-0.007 \text { * } \\
(0.00)\end{array}$ & $\begin{array}{l}0.003 \\
(0.01)\end{array}$ \\
\hline $\mathrm{SI}_{\mathrm{NMKT}}$ & & $\begin{array}{c}-0.013^{* * *} \\
(0.00)\end{array}$ & $\begin{array}{c}-0.011^{* * *} \\
(0.00)\end{array}$ & $\begin{array}{c}-0.001 \\
(0.00)\end{array}$ \\
\hline IENUSE & $\begin{array}{c}1.190 * * * \\
(0.03)\end{array}$ & $\begin{array}{c}1.159^{* * *} \\
(0.03)\end{array}$ & $\begin{array}{c}1.157^{* * * *} \\
(0.03)\end{array}$ & $\begin{array}{c}1.124^{* * *} \\
(0.03)\end{array}$ \\
\hline URB & $\begin{array}{c}0.002 * * \\
(0.00)\end{array}$ & $\begin{array}{c}0.003^{* * *} \\
(0.00)\end{array}$ & $\begin{array}{c}0.003^{* * *} \\
(0.00)\end{array}$ & $\begin{array}{l}0.001 \\
(0.00)\end{array}$ \\
\hline $\mathrm{EU} * \mathrm{SI}_{\mathrm{MKT}}$ & & & & $\begin{array}{c}-0.015 * \\
(0.01)\end{array}$ \\
\hline $\mathrm{EU}^{*} \mathrm{SI}_{\mathrm{NMKT}}$ & & & & $\begin{array}{c}-0.019^{* * *} \\
(0.00)\end{array}$ \\
\hline Constant & $\begin{array}{c}-11.164^{* * *} \\
(0.57)\end{array}$ & $\begin{array}{c}-10.479 * * * \\
(0.62)\end{array}$ & $\begin{array}{c}-10.392^{* * *} \\
(0.62)\end{array}$ & $\begin{array}{c}-9.970 * * * \\
(0.60)\end{array}$ \\
\hline $\mathrm{R}^{2} \mathrm{adj}$ & 0.83 & 0.83 & 0.84 & 0.85 \\
\hline N.obs & 672 & 672 & 672 & 672 \\
\hline
\end{tabular}

Table 3. Fixed Effects Model—Quadratic Specification.

Dependent Variable: $1 \mathrm{CO}_{2}$. Robust Standard Errors in parentheses. ${ }^{* * *}$ Significant at $1 \%$. ${ }^{* *}$ Significant at $5 \%$. * Significant at $10 \%$.

Column (4) of Table 3 presents results for model (1a), where we want to assess whether there are differences in the effect of the stringency of the environmental policies between EU and non-EU countries. Both $\mathrm{SI}_{\mathrm{MKT}}$ and $\mathrm{SI}_{\mathrm{NMKT}}$ lose significance, but the interacted terms are both negative and significantly different from zero, showing that in applying environmental policies, EU countries are more effective than non-EU countries. While the results of column 4 confirm the inverted U-shaped relationship, the turning point is estimated to be at a higher GDP per capita (around 6,500 US dollars).

Even if the EKC is proven, the time necessary to reach a decrease in the emissions is not explained. Indeed, the achievement of the maximum and the abatement of emissions can appear only in the long 
run. Some scholars disagreeing with the EKC application claim that the heterogeneous estimated thresholds (i.e., the maximums of the bell curve) can hold for an indeterminate long period, without achieving a decrease in emissions, while the environmental problem requires a short run correction [36]. While the turning points estimated in column (4) of Table 3 are in line with the ones obtained in the literature [14,15], if we consider the log of GDP per capita of the countries included in the sample in 2016, the only country under the threshold is India. Therefore, even China, Indonesia, Brazil, South Africa, and Turkey should be in the descendent part of the EKC, where economic growth is accompanied by a decrease in emissions. However, the reduction in $\mathrm{CO}_{2}$ emissions achieved by the environmental policies of EU members is sharper than those implemented by non-EU countries.

This difference between the two subgroups depends on some components that require deeper investigation in future. Surely, international agreements have some relevance. Most of the European countries applied very restrictive policies. This dissimilar effort can be explained by the application of the "different responsibilities" principle, and to the fact that the EU ETS has been introduced in 2005, almost 8 years before the pilot applications in some Chinese regions. The same path is observed for carbon taxes, applied in some Northern European Countries in the early 1990s.

Table 4 shows the results of the cubic specification (2) in columns (1) to (3), as well as the estimates for the enriched specification (2a) with the two interacted terms $\mathrm{EU}^{*} \mathrm{SI}_{\mathrm{MKT}}$ and $\mathrm{EU}^{*} \mathrm{SI}_{\mathrm{NMKT}}$ (column 4).

Since the coefficient of the cubic term is positive and significant, the inverted U-shaped function is replaced by a N-shaped relationship. Therefore, after reaching a maximum, emissions start to reduce, but the intermediate phase of improvement is followed by a subsequent phase of deterioration. However, since the (local) maximum occurs when lGDP is around 8 and the (local) minimum when it is equal to 13.4, the results are not dramatically different with respect to the ones presented in Table 3, because the second turning point (trough) is at very high and implausible levels of GDP per capita. Also, it is interesting to note that the impact on emissions of the stringency indices, especially for EU countries, are still negative and significant, which adds robustness to our previous results.

Table 4. Fixed Effects Model—Cubic Specification.

\begin{tabular}{|c|c|c|c|c|}
\hline & (1) & (2) & (3) & (4) \\
\hline lGDP & $\begin{array}{c}3.950 * * * \\
(1.47)\end{array}$ & $\begin{array}{c}4.710^{* * *} \\
(1.48)\end{array}$ & $\begin{array}{c}4.671^{* * *} \\
(1.47)\end{array}$ & $\begin{array}{c}3.824^{* * *} \\
(1.42)\end{array}$ \\
\hline $1 \mathrm{GDP}^{2}$ & $\begin{array}{c}-0.389^{* *} \\
(0.16)\end{array}$ & $\begin{array}{c}-0.479 * * * \\
(0.16)\end{array}$ & $\begin{array}{c}-0.476^{* * *} \\
(0.16)\end{array}$ & $\begin{array}{c}-0.384 \text { ** } \\
(0.16)\end{array}$ \\
\hline $1 G D P^{3}$ & $\begin{array}{c}0.012^{* *} \\
(0.01)\end{array}$ & $\begin{array}{c}0.016^{* * *} \\
(0.01)\end{array}$ & $\begin{array}{c}0.016^{* * *} \\
(0.01)\end{array}$ & $\begin{array}{c}0.012^{* *} \\
(0.01)\end{array}$ \\
\hline $\mathrm{SI}_{\mathrm{MKT}}$ & $\begin{array}{c}-0.013^{* * *} \\
(0.00)\end{array}$ & & $\begin{array}{c}-0.007 \text { * } \\
(0.00)\end{array}$ & $\begin{array}{l}0.002 \\
(0.01)\end{array}$ \\
\hline $\mathrm{SI}_{\mathrm{NMKT}}$ & & $\begin{array}{c}-0.015^{* * *} \\
(0.00)\end{array}$ & $\begin{array}{c}-0.013^{* * *} \\
(0.00)\end{array}$ & $\begin{array}{l}-0.002 \\
(0.00)\end{array}$ \\
\hline 1ENUSE & $\begin{array}{c}1.200 * * * \\
(0.03)\end{array}$ & $\begin{array}{c}1.167^{* * *} \\
(0.03)\end{array}$ & $\begin{array}{c}1.165^{* * * *} \\
(0.03)\end{array}$ & $\begin{array}{c}1.131^{* * *} \\
(0.03)\end{array}$ \\
\hline URB & $\begin{array}{c}0.002 \text { * } \\
(0.00)\end{array}$ & $\begin{array}{c}0.003 * * * \\
(0.00)\end{array}$ & $\begin{array}{c}0.003 * * * \\
(0.00)\end{array}$ & $\begin{array}{l}0.001 \\
(0.00)\end{array}$ \\
\hline $\mathrm{EU}{ }^{*} \mathrm{SI}_{\mathrm{MKT}}$ & & & & $\begin{array}{c}-0.014 \text { * } \\
(0.01)\end{array}$ \\
\hline $\mathrm{EU} * \mathrm{SI}_{\mathrm{NMKT}}$ & & & & $\begin{array}{c}-0.019 * * * \\
(0.00)\end{array}$ \\
\hline Constant & $\begin{array}{c}-20.452^{* * *} \\
(4.49)\end{array}$ & $\begin{array}{c}-22.405^{* * *} \\
(4.48)\end{array}$ & $\begin{array}{c}-22.280^{* * *} \\
(4.48)\end{array}$ & $\begin{array}{c}-19.462^{* * *} \\
(4.32)\end{array}$ \\
\hline$R^{2}$ adj & 0.83 & 0.84 & 0.84 & 0.85 \\
\hline N.obs & 672 & 672 & 672 & 672 \\
\hline
\end{tabular}

Dependent Variable: $1 \mathrm{CO}_{2}$. Robust Standard Errors in parentheses. ${ }^{* * *}$ Significant at $1 \% .{ }^{* *}$ Significant at $5 \%$. * Significant at $10 \%$. 
As a final exercise, we verify the effectiveness of policies by splitting the dataset into two sub-periods, 1992-2004 and 2005-2012, using as a cutting point the year in which the Kyoto Protocol entered into force as well as the European ETS was introduced. To test the existence of a structural break, we use a Chow Test. The F statistics are very high (i.e., $F=789.83$ for the quadratic specification), suggesting the existence of a relevant change in the coefficients. Columns 1 and 3 of Table 5 confirm for the years 1992-2004 the U-shaped and N-shaped relationships, respectively, while for the years 2005-2012 the coefficients associated with lGDP are not significant anymore, a result which is often encountered in the literature.

Table 5. Fixed Effects Models-Sub-periods.

\begin{tabular}{|c|c|c|c|c|}
\hline & \multicolumn{4}{|c|}{ Dependent Variable: $1 \mathrm{CO}_{2}$} \\
\hline & \multicolumn{2}{|c|}{ Quadratic Specification } & \multicolumn{2}{|c|}{ Cubic Specification } \\
\hline & 1992-2004 & 2005-2012 & 1992-2004 & 2005-2012 \\
\hline & (1) & (2) & (3) & (4) \\
\hline lGDP & $\begin{array}{c}0.411^{* * *} \\
(0.14)\end{array}$ & $\begin{array}{l}0.346 \\
(0.65)\end{array}$ & $\begin{array}{c}7.755^{* * *} \\
(1.61)\end{array}$ & $\begin{array}{l}-2.497 \\
(7.94)\end{array}$ \\
\hline $1 G D P^{2}$ & $\begin{array}{c}-0.029^{* * *} \\
(0.01)\end{array}$ & $\begin{array}{c}-0.018 \\
(0.03)\end{array}$ & $\begin{array}{c}-0.839 * * * \\
(0.18)\end{array}$ & $\begin{array}{l}0.287 \\
(0.85)\end{array}$ \\
\hline $1 G D P^{3}$ & & & $\begin{array}{c}0.029^{* * *} \\
(0.01)\end{array}$ & $\begin{array}{l}-0.011 \\
(0.03)\end{array}$ \\
\hline $\mathrm{SI}_{\mathrm{MKT}}$ & $\begin{array}{c}-0.009 \\
(0.01)\end{array}$ & $\begin{array}{l}0.022 \\
(0.02)\end{array}$ & $\begin{array}{c}-0.001 \\
(0.01)\end{array}$ & $\begin{array}{l}0.022 \\
(0.02)\end{array}$ \\
\hline $\mathrm{SI}_{\mathrm{NMKT}}$ & $\begin{array}{c}-0.004 \\
(0.01)\end{array}$ & $\begin{array}{l}0.005 \\
(0.01)\end{array}$ & $\begin{array}{c}-0.004 \\
(0.01)\end{array}$ & $\begin{array}{l}0.006 \\
(0.01)\end{array}$ \\
\hline IENUSE & $\begin{array}{c}1.110^{* * *} \\
(0.04)\end{array}$ & $\begin{array}{c}1.326^{* * *} \\
(0.07)\end{array}$ & $\begin{array}{c}1.128^{* * *} \\
(0.04)\end{array}$ & $\begin{array}{c}1.325^{* * *} \\
(0.07)\end{array}$ \\
\hline URB & $\begin{array}{c}0.003 \text { * } \\
(0.00)\end{array}$ & $\begin{array}{c}-0.002 \\
(0.00)\end{array}$ & $\begin{array}{l}0.002 \\
(0.00)\end{array}$ & $\begin{array}{l}-0.003 \\
(0.00)\end{array}$ \\
\hline $\mathrm{EU}^{*} \mathrm{SI}_{\mathrm{MKT}}$ & $\begin{array}{c}-0.003 \\
(0.01)\end{array}$ & $\begin{array}{c}-0.026^{* *} \\
(0.01)\end{array}$ & $\begin{array}{c}-0.011 \\
(0.01)\end{array}$ & $\begin{array}{c}-0.027^{* *} \\
(0.01)\end{array}$ \\
\hline $\mathrm{EU} * \mathrm{SI}_{\mathrm{NMKT}}$ & $\begin{array}{l}0.005 \\
(0.01)\end{array}$ & $\begin{array}{c}-0.023 * \\
(0.01)\end{array}$ & $\begin{array}{l}0.004 \\
(0.00)\end{array}$ & $\begin{array}{c}-0.023 * \\
(0.01)\end{array}$ \\
\hline Constant & $\begin{array}{c}-8.306^{* * *} \\
(0.69)\end{array}$ & $\begin{array}{c}-10.207^{* * *} \\
(2.92)\end{array}$ & $\begin{array}{c}-30.207^{* * *} \\
(4.83)\end{array}$ & $\begin{array}{l}-1.394 \\
(24.71)\end{array}$ \\
\hline $\mathrm{R}^{2} \mathrm{adj}$ & 0.81 & 0.76 & 0.82 & 0.76 \\
\hline N.obs & 416 & 256 & 416 & 256 \\
\hline
\end{tabular}

Dependent Variable: $1 \mathrm{CO}_{2}$. Robust Standard Errors in parentheses. ${ }^{* * *}$ Significant at $1 \% .{ }^{* *}$ Significant at $5 \%$. * Significant at $10 \%$.

Conversely, policies seem to be ineffective in the first period and strongly effective, for EU countries, in the years 2005-2012.

Overall, some interesting features emerge from the split of the sample according to time. The period 1992-2004 shows patterns similar to those found for the entire sample, where both a quadratic relationship and, more importantly, a cubic specification between $\mathrm{CO}_{2}$ emissions and GDP may apply. However, the stringency measures do not display any role, neither within the EU, nor in the non-EU countries. For the period 2005-2012, the quadratic specification (column (2), Table 5) exhibits a role for GDP similar in magnitude to the one found for the period 1992-2004, even if less precisely estimated, probably because of the reduced number of observations (416 observations in the period 1992-2004 versus 256 in the period 2005-2012). On the contrary, the cubic specification (column (4), Table 5) seems to be rejected in this sub-period by the data: the coefficients for 1GDP, $1 G D P^{2}$, and $1 G^{2} P^{3}$ are very imprecisely estimated, with large standard errors, and they also show the reversed signs. The estimated coefficients for the SIs are similar across the two specifications, for the period 2005-2012: in the EU countries, the increase in the stringency of market instruments contributed to decrease $\mathrm{CO}_{2}$ emissions, 
while the role of non-market policies was slightly smaller. Notice that the stringency of environmental policies increased in all countries: the average $\mathrm{SI}_{\mathrm{MKT}}$ for the period 1992-2004 is 0.744, while for the 2005-2012 period it is 1.701; the average $\mathrm{SI}_{\mathrm{NMKT}}$ for the period 1992-2004 is 1.569, while it raises to 2.971 in the 2005-2012 period. A longer time span is probably required for a complete assessment of the effects on $\mathrm{CO}_{2}$ emissions.

\section{Conclusions}

The paper studies the nexus between $\mathrm{CO}_{2}$ emissions and economic growth for a sample of 32 European and non-European countries observed over the years 1992-2012. Beyond testing for the existence of the so-called EKC, using both quadratic and cubic specifications, our main interest is to evaluate the role of environmental policies, an angle which has been, surprisingly, neglected in the empirical literature [18].

Our main results point to the presence of a cubic relationship between per capita $\mathrm{CO}_{2}$ emissions and per capital GDP, for the full sample. This $\mathrm{N}$-shaped relationship, however, does not completely contrast with a quadratic specification, as the first turning point (peak) of the cubic specification almost coincide with the peak of the inverted U-shape curve. We also find that the second turning point of the cubic N-shaped relationship happens to be at very high GDP levels. Even if the deterioration of environment re-occurs for very high levels of GDP, this result is comfortingly, as it is often found in the environmental economics literature. The important implication that can be derived is that economic growth cannot be considered as both the solution and the cause of environmental degradation.

Since government interventions are called for to abate emissions, we test for the role of environmental policies. In particular, we introduce two SIs in the estimation of our Kuznets curves. We find that more stringent policy interventions actually reduce $\mathrm{CO}_{2}$ emissions. This result is particularly strong within the EU countries and in the post 2005 period (when European ETS and the Kyoto Protocol became effective).

Due to the continuous increase in the stringency of the policies, to satisfy the targets set by the International Agreements, market-based instruments are becoming dramatically important. Firms should therefore put more effort to correct their emissions, implementing new ecofriendly technologies, and governments should put more effort in monitoring the behaviors of firms and citizens. To stimulate the efforts of entrepreneurs and customers in the renewing process, different means, such as subsidies, can be applied, since switching from more traditional ways of producing (and consuming) to environmentally friendly ones is costly [37].

Given this early promising results, further research is called for. Ideally, if more reliable measures of environmental policy stringency and efficacy are available, a larger sample, including more countries and more years, could be analyzed.

Author Contributions: Formal analysis, E.M.d.A., M.D.G. and D.V.; Investigation, E.M.d.A., M.D.G. and D.V.; Writing—original draft, E.M.d.A., M.D.G. and D.V.

Funding: This work was supported by the local research funds of the University of Torino. Marina Di Giacomo and Davide Vannoni gratefully acknowledge the financial support of MIUR - Ministry of Education, University and Research (Financing Fund for Departments of Excellence).

Acknowledgments: We thank seminar participants at Rennes and at Turin University. Special thanks to Isabelle Cadoret for comments and suggestions.

Conflicts of Interest: The authors declare no conflict of interest.

\section{References}

1. Albrizio, S.; Botta, E.; Koźluk, T.; Zipperer, V. Do Environmental Policies Matter for Productivity Growth? Insights from new Cross- Country Measures of Environmental Policies; OECD Economics Department Working Papers No. 1176; OECD: Paris, France, 2014.

2. Zrelli, M.H. Renewable Energy, Non-Renewable Energy, Carbon Dioxide Emissions and Economic Growth in Selected Mediterranean Countries. Environ. Econ. Policy Stud. 2017, 19, 691-709. [CrossRef] 
3. Botta, E.; Kozluk, T. Measuring Environmental Policy Stringency in OECD Countries: A Composite Index Approach; OECD Economic Department Working Papers No. 1177; OECD: Paris, France, 2014.

4. Porter, M.E.; van der Linde, C. Towards a new Conception of the Environmental Competitiveness Relationship. J. Econ. Perspect. 1995, 9, 97-118. [CrossRef]

5. Ambec, S.; Cohen, M.A.; Elgie, S.; Lanoie, P. The Porter Hypothesis at 20: Can Environmental Regulation Enhance Innovation and Competitiveness? Rev. Environ. Econ. Policy 2013, 7, 2-22. [CrossRef]

6. Kuznets, S. Economic Growth and Income Inequality. Am. Econ. Rev. 1955, 45, 1-28.

7. Grossman, G.M.; Krueger, A.B. Environmental Impacts of a North American Free Trade Agreement; NBER Working Paper No. 3914; National Bureau of Economic Research: Cambridge, MA, USA, 1991.

8. Grossman, G.M.; Krueger, A.B. Economic Growth and the Environment. Q. J. Econ. 1995, 110, $353-377$. [CrossRef]

9. Shafik, N.; Bandyopadhyay, S. Economic Growth and Environmental Quality, Time- Series and Cross Country Evidence; Policy Research Working Paper No. 904. World Development Report; The World Bank: Washington, DC, USA, 1992.

10. Panayotou, T. Economic Growth and the Environment, Economic Survey of Europe; UNECE: New York, NY, USA; Geneva, Schweizerische, 2003; Volume 2.

11. Holtz-Eakin, D.; Selden, T.M. Stoking the Fires? $\mathrm{CO}_{2}$ emissions and Economic growth. J. Public Econ. 1995, 57, 85-101. [CrossRef]

12. Özokcu, S.; Özdemir, Ö. Economic Growth, Energy, and Environmental Kuznets Curve. Renew. Sustain. Energy Rev. 2017, 72, 639-647. [CrossRef]

13. Galeotti, M.; Manera, M.; Lanza, A. On the Robustness of Robustness Checks of the Environmental Kuznets Curve Hypothesis. Environ. Resour. Econ. 2009, 42, 551-574. [CrossRef]

14. Dinda, S. Environmental Kuznets Curve Hypothesis: A Survey. Ecol. Econ. 2004, 49, 431-455. [CrossRef]

15. Lee, C.C.; Chiu, Y.B.; Sun, C.H. Does One Size Fit All? A Reexamination of the Environmental Kuznets Curve Using the Dynamic Panel Data Approach. Rev. Agric. Econ. 2009, 31, 751-778. [CrossRef]

16. Sterpu, M.; Soava, G.; Mehedintu, A. Impact of Economic Growth and Energy Consumption on Greenhouse Gas Emissions: Testing Environmental Curves Hypotheses on EU Countries. Sustainability 2018, 10, 3327. [CrossRef]

17. Liu, H.; Kim, H.; Liang, S.; Kwon, O.S. Export Diversification and Ecological Footprint: A Comparative Study on EKC Theory Among Korea, Japan, and China. Sustainability 2018, 10, 3657. [CrossRef]

18. Cadoret, I.; Padovano, F. The Political Drivers of Renewable Energies Policies. Energy Econ. 2016, 56, 261-269. [CrossRef]

19. Lagreid, O.M.; Povitkina, M. Do Political Institutions Moderate the GDP-CO Relationship? Ecolog. Econ. 2018, 145, 441-450. [CrossRef]

20. Shapiro, J.; Walker, R. Why is Pollution from US Manufacturing Declining? The Roles of Environmental Regulation, Productivity and Trade. Am. Econ. Rev. 2018, 108, 3814-3854. [CrossRef]

21. Levinson, A.; Taylor, S. Unmasking the pollution Haven Effect. Int. Econ. Rev. 2004, 49, 223-254. [CrossRef]

22. Brunel, C.; Levinson, A. Measuring Environmental Regulatory Stringency; OECD Working Paper; OECD: Paris, France, 2013.

23. Fisher, C.; Newell, R. Environmental and technology policies for climate mitigation. J. Environ. Econ. Manag. 2008, 55, 142-162. [CrossRef]

24. Galeotti, M.; Salini, S.; Verdolini, E. Measuring Environmental Policy Stringency: Approaches, Validity, and Impact on Energy Efficiency; Centro Studi Luca d'Agliano Development Studies Working Paper No. 412; Centro Studi Luca d'Agliano: Milano, Italy, 2017.

25. De Serres, A.; Murtin, F.; Nicoletti, G. A Framework for Assessing Green Growth Policies; OECD Economics Department Working Papers No. 774; OECD: Paris, France, 2010.

26. Azuela, G.E.; Barroso, L.A. Design and Performance of Policy Instruments to Promote the Development of Renewable Energy: Emerging Experience in Selected Developing Countries; World Bank: Washington, DC, USA, 2012.

27. Goulder, L.H.; Schein, A. Carbon Taxes Versus Cap and Trade: A Critical Review. Clim. Chang. Econ. 2013, 4, 1-28. [CrossRef]

28. OECD. Towards Green Growth?: Tracking Progress; OECD Green Growth Studies; OECD Publishing: Paris, France, 2015. [CrossRef]

29. Fullerton, D.; Wu, W. Policies for Green Design. J. Environ. Econ. Manag. 1998, 36, 131-148. [CrossRef] 
30. World Bank and Ecofys. State and Trends of Carbon Pricing 2018; World Bank: Washington, DC, USA, 2018.

31. Dijkgraaf, E.; Vollebergh, H.R. A Note on Testing for Environmental Kuznets Curves with Panel Data; FEEM Working Paper n. 2001.063; Fondazione Eni Enrico Mattei: Milan, Italy, 2001.

32. Dasgupta, S.; Wheeler, D.; Roy, S.; Mody, A. Environmental Regulation and Development: A Cross-Country Empirical Analysis. Oxf. Dev. Stud. 2001, 29, 173-187. [CrossRef]

33. Eliste, P.; Fredriksson, P.G. Environmental Regulations, Transfers, and Trade: Theory and Evidence. J. Environ. Econ. Manag. 2002, 43, 234-250. [CrossRef]

34. European Bank for Reconstruction and Development. The Low Carbon Transition; EBRD: London, UK, 2011.

35. World Economic Forum. Global Agenda Survey; World Economic Forum: Geneva, Switzerland, 2011.

36. Stern, D.I. Between Estimates of the Emissions-Income Elasticity. Ecol. Econ. 2010, 69, 2173-2182.

37. OECD. Taxation, Innovation and the Environment; OECD: Paris, France, 2010.

(C) 2019 by the authors. Licensee MDPI, Basel, Switzerland. This article is an open access article distributed under the terms and conditions of the Creative Commons Attribution (CC BY) license (http://creativecommons.org/licenses/by/4.0/). 